\title{
TMSB15A Gene
}

National Cancer Institute

\section{Source}

National Cancer Institute. TMSB15A Gene. NCI Thesaurus. Code C128267.

This gene plays a role in both actin binding and cytoskeletal remodeling. 